\title{
HETEROGENEOUS REBURNING BY MIXED FUELS
}

Final Report

September 25, 2002 - September 24, 2004

Wei-Yin Chen

Benson B. Gathitu

January 14, 2005

Work Performed under the Grant DE-FG26-02NT41552

Department of Chemical Engineering

Anderson Hall

P.O. Box 1848

University of Mississippi

University, MS 38677-9740

\author{
Submitted to \\ U.S. Department of Energy \\ National Energy Technology Laboratory \\ 626 Cochrans Mills Road, P.O. Box 10940 \\ Pittsburgh, PA 15236-0940
}




\section{DISCLAIMER}

This report was prepared as an account of work sponsored by an agency of the United States Government. Neither the United States Government nor any agency thereof, nor any of their employees, makes warranty, express or implied, or assumes any legal liability or responsibility for the accuracy, completeness, or usefulness of any information, apparatus, product, or process disclosed, or represents that its use would not infringe privately owned rights. Reference herein to any specific commercial product, process, or service by trade name, trademark, manufacturer, or otherwise does not necessarily constitute or imply its endorsement, recommendation, or favoring by the United States Government or any agency thereof. The views and opinions of authors expressed herein do not necessarily state or reflect those of the United States Government or any agency thereof. 


\begin{abstract}
Recent studies of heterogeneous reburning, i.e., reburning involving a coal-derived char, have elucidated its variables, kinetics and mechanisms that are valuable to the development of a highly efficient reburning process. Young lignite chars contain catalysts that not only reduce NO, but they also reduce HCN that is an important intermediate that recycles to NO in the burnout zone. Gaseous CO scavenges the surface oxides that are formed during NO reduction, regenerating the active sites on the char surface. Based on this mechanistic information, cost-effective mixed fuels containing these multiple features has been designed and tested in a simulated reburning apparatus. Remarkably high reduction of NO and HCN has been observed and it is anticipated that mixed fuel will remove $85 \%$ of NO in a three-stage reburning process.
\end{abstract}




\section{ACKNOWLEDGMENT}

The Lignite Energy Council and the Energy and Environmental Research Center of the University of North Dakota provided us the ashes of lignite and sub-bituminous coal from the utilities. The Institute for Thermal Power Engineering of Zhejiang University provided us a sample of blended bituminous coal and lignite that has been used by a Chinese utility.

The project cannot be fulfilled without the financial support of the National Energy Technology Laboratory of the US Department of Energy, to whom the authors are grateful. 


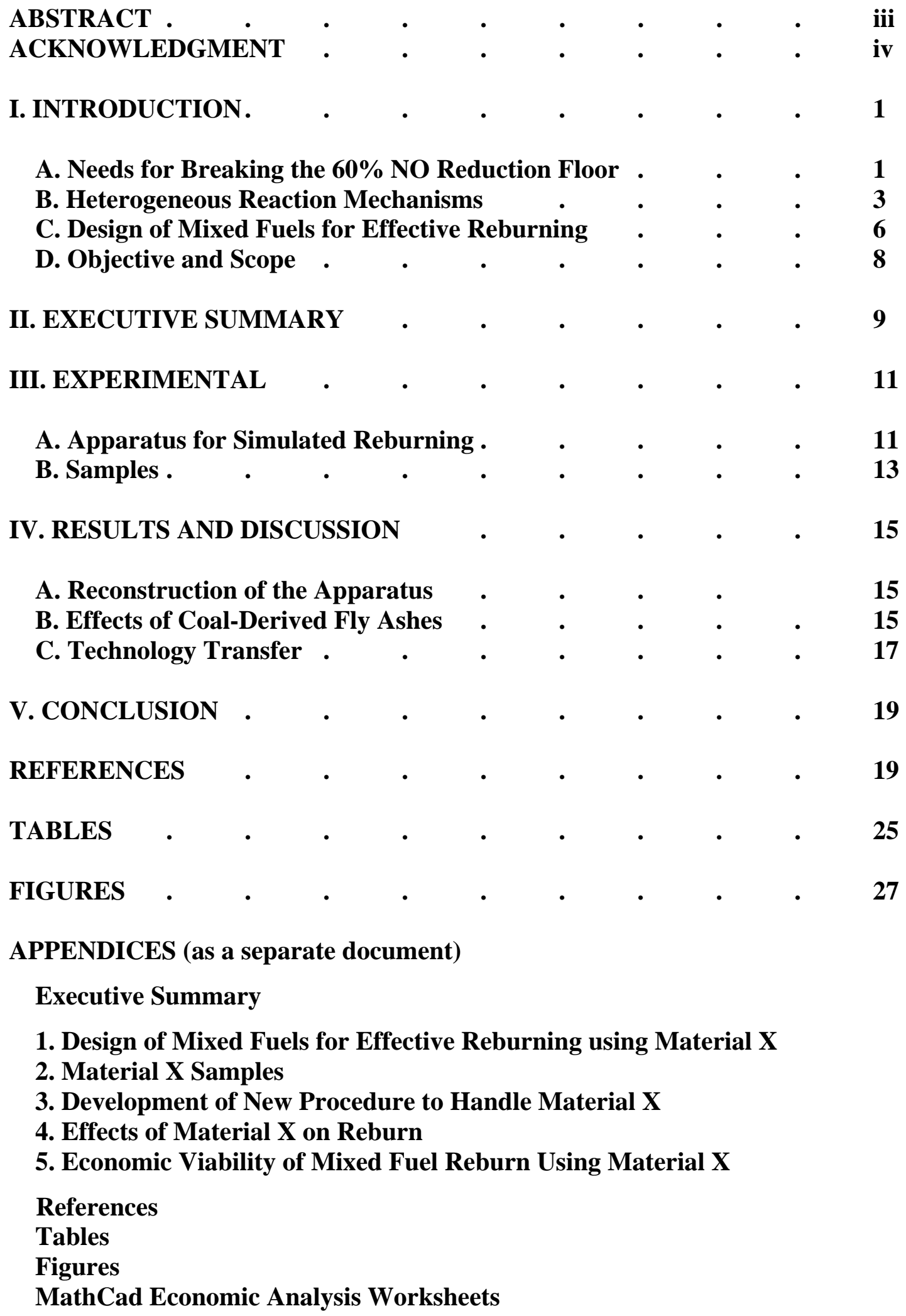




\section{INTRODUCTION}

\section{A. Needs for Breaking the $60 \%$ NO Reduction Floor}

Nitrogen oxide, NO, is one of the six criteria air pollutants regulated by the National Ambient Air Quality Standard (NAAQS) in 1991 due to its detrimental effects on public health and environment. Specifically, it reacts with oxygen and water to form nitric acid that destroys trees, kills aquatic life in stream and lakes, and damages buildings and statues. It also reacts with hydrocarbons and forms ozone and smog through photochemical reactions that reduce visibility and pose risk to public health.

Stationary combustion processes contribute to about 50\% of the global nitrogen oxide production. The stringent Clean Air Act and its Amendments (CAAA) have effectively reduced their emissions in the last three decades. One of the CAAA philosophies is to establish emission standards based on the "best technologies," or the "new source performance standards," or NSPS in short, that are updated periodically. The CAAA of 1990 set $\mathrm{NO}_{\mathrm{x}}$ emissions at 0.5 or $0.6 \mathrm{lb} / \mathrm{Mbtu}$ (in its oxidized form, $\mathrm{NO}_{2}$ ), depending on the rank of coal, which has been achieved largely by installing low- $\mathrm{NO}_{\mathrm{x}}$ burners (LNB).

As the second philosophy, the CAAA of 1990 took into account the air quality standards in establishing its regulations. For ozone non-attainment areas, the emission standards are especially stringent. Regulatory actions resulting from the revised NAAQS for ozone and particulate matter smaller than 2.5 microns $\left(\mathrm{PM}_{2.5}\right)$ require source emission reductions of $\mathrm{NO}_{\mathrm{x}}$ to $0.15 \mathrm{lb} / \mathrm{Mbtu}$ for much of the nation. In addition, caps proposed under the Clear Skies Initiative require some plants to reduce $\mathrm{NO}_{\mathrm{x}}$ emissions to 0.15 $\mathrm{lb} / \mathrm{Mbtu}$ and eventually to as low as $0.11 \mathrm{lb} / \mathrm{Mbtu}$. Selective catalytic reduction (SCR) is 
the only technology now capable of achieving such low emissions, but it costs $\$ 80$ $\$ 120 / \mathrm{kW}$, or $\$ 2,000 /$ ton of $\mathrm{NO}_{\mathrm{x}}$. Consequently, cost-effective, advanced $\mathrm{NO}_{\mathrm{x}}$ reduction technologies have to be developed.

Reburning, see Figure 1, is an emerging three-stage, in-furnace combustion technology designed for the reduction of NO by introducing a small amount of reburning fuel above the primary flame where the majority of NO is chemically reduced to nitrogen in this fuel rich environment. Wendt et al. introduced the reburning concept and their experimental results in 1973. Tests on a full-scale, three-staged boiler at Mitsubishi Heavy Industries (Takahashi et al., 1983) resulted in over 50\% reduction of the NO produced in the primary flame. Reburning is attractive because it can retrofit old boilers at a relatively low operation cost than the post combustion technologies, such as SCR.

Pilot- and full-scale research in the last three decades, however, has demonstrated a floor, about $60 \%$ of NO produced in the primary flames, in either gas or coal reburning, below that floor NO cannot be reduced further. The equilibrium NO concentrations are about two orders of magnitudes higher than those observed experimentally, suggesting the reburning reaction is kinetically controlled. In addition, evidence suggests that the nitrogen-containing reaction intermediates, including HCN and char, are likely the major causes of the observed NO reduction floor exiting from a three-staged process. During natural gas reburning, hydrocarbon free radicals, including $\mathrm{C} \cdot \mathrm{CH} \cdot$ and $\mathrm{CH}_{2} \cdot$, effectively convert NO to HCN, a major reaction product in the reburning zone (Miller and Bowman, 1989; Burch et al., 1991). However, a significant portion of this HCN oxidizes to form NO in the burnout zone and this limits the overall NO reduction efficiency. During coal reburning, a significant portion of the char nitrogen oxidizes to form NO in the burnout 
zone (see, e.g., Molina et al., 2000), which also places a cap on the overall NO reduction efficiency. Therefore, to break these limitations in either gas or coal reburning, future development has to focus on means to simultaneously minimize the productions of NO, and its reaction intermediates, HCN and char in the reburning zone. To achieve this goal, our efforts in the past have been targeted at fundamental elucidation of the reburning reaction mechanisms in a more detailed level.

\section{B. Heterogeneous Reaction Mechanisms}

Our early research suggested that lignite from Mississippi and North Dakota have reburning efficiencies comparable to that of methane (Burch et al., 1991; 1994). Moreover, it has been demonstrated that, in contrast to the findings derived from the bituminous coals, heterogeneous reactions on the lignite char surface contribute high NO reductions that are comparable to gas phase NO reactions (Chen and Ma, 1996). The effectiveness of lignite during reburning has also been demonstrated in a 1.0 and a 0.1 Mbtu/hr pilot scale combustion facilities (Payne et al., 1995; Pershing, 1995). Recently, Chen and Tang (2001) extensively studied the variables, kinetics and mechanisms of reburning with chars. They found that the efficiency of heterogeneous reburning depends on the origin of the char, char preparation history, and the presence of oxidants, $\mathrm{CO}_{2}$ and $\mathrm{O}_{2}$, and the reducing agent, CO. In addition to its large internal surface area, evidences suggest that the effectiveness of lignite char is attributable to its ability to promote two consecutive reactions: 1 ) the catalytic gasification of char by $\mathrm{CO}_{2}$ and $\mathrm{O}_{2}$ for production of $\mathrm{CO}$, and, 2) the scavenge of surface oxygen complexes, $\mathrm{C}(\mathrm{O})$, including those formed after adsorption of $\mathrm{NO}$, by gaseous $\mathrm{CO}$, for the regeneration of reactive sites. More 
interestingly, lignite ash also catalyzes the decomposition of HCN, a major intermediate of NO conversion and a major contributor of the $60 \%$ reduction floor during gas reburn. These reaction mechanisms can be viewed from three major aspects: char gasification, catalytic roles of minerals, and role of gaseous CO, which are discussed in more detail below.

Char Gasification by $\mathrm{NO}, \mathrm{O}_{2}$ and $\mathrm{CO}_{2}$

It is generally believed that (e.g., Mims, 1991; Illan-Gomez et al., 1996) char gasification by NO, similar to the catalytic gasification of carbon by other oxidizing agents, involves the following kinetically-controlled elementary steps: a) chemisorption of NO on the catalyst, b) transfer of oxygen from the catalytically active sites to the carbon reactive sites, and c) desorption of oxygen from the carbon surface. It is known that alkali and alkaline earth metals, including K, Na, Ca and Mg (Allen, 1991; Hansen et al., 1992; Hansen and Dam-Johansen, 1993; Shimizu et al., 1993; Lin et al., 1993; Illan-Gomez et al., 1995a-e; Illan-Gomez et al., 1996; Guo and Hecker, 1996; Garcia-Garcia et al., 1997; Jensen et al., 1997; Bueno-Lopez et al., 2002), catalyze reductions of NO in fuel-rich, oxidizing environments. Chars with high content of catalytic constituents are expected to promote reactions steps a) and b) above, rendering the desorption step, c), a rate controlling step in the overall char oxidation mechanism.

\section{Catalytic Roles of Minerals in Chars}

In addition to the catalytic reduction of NO, the minerals in lignite also participate in two types of reactions that indirectly enhance NO reduction in the reburning process: 
- catalytic conversion of HCN, and,

- production of gaseous CO through catalytic gasification of char.

HCN and $\mathrm{NH}_{3}$ are the two major stable reaction intermediates before NO is chemically reduced to $\mathrm{N}_{2}$ in fuel-rich environments (Miller and Bowman, 1989; Burch et al., 1994). Burch et al. (1991) and Chen and Tang (2001) demonstrated that lignite char catalytically converts $\mathrm{HCN}$ by lignite ash to amine radicals, $\mathrm{NH}_{\mathrm{i}}$ and other species. Over $60 \%$ of $\mathrm{NO}$ at temperatures greater than $1100^{\circ} \mathrm{C}$ is converted to $\mathrm{HCN}$ in the reburning stage when natural gas is used (Burch et al., 1991). About $60 \%$ of HCN recycles back to NO with a smaller fraction of the HCN is converted to $\mathrm{N}_{2}$ in the burnout zone. Recycle of amines to NO in the burnout zone, however, is much lower. By introducing a small amount of lignite ash produced by a Bunsen burner, the yield of total fixed nitrogen (or TFN in short, i.e., the total yields of $\mathrm{NO}, \mathrm{HCN}$ and $\mathrm{NH}_{3}$ ) reduces from 900 to $200 \mathrm{ppm}$ in methane reburning at stoichiometry 0.9 . Increasing the amount of lignite ash is expected to further reduce HCN in the reburning zone, and therefore the final NO yield from the burnout zone. Since HCN recycling to NO is the major contributor of the NO reduction floor, the addition of catalytic minerals consists a corner stone in our design of a multi-functional reburning fuel in the present project.

Radovic et al. (1983), Hengel and Walker (1984), and Lizzio et al. (1990) found that mineral matters in lignite catalyze the char oxidation, and thus the yields of their oxidation products, $\mathrm{CO}$ and $\mathrm{CO}_{2}$, are much higher than those from the gasification of high rank coals. Chen and Tang (2001) reported a higher CO concentration, 2 to 3\%, in simulated lignite-reburning zone than that in a bituminous-coal reburning zone. As it is discussed below, gaseous CO increases the oxygen turnover rate on the char surface and, 
therefore, enhances NO reduction.

Role of $\mathrm{CO}$

Chen and Tang (2001) found that the remarkable effectiveness of lignite char in reburning appears to be attributable to its ability to promote two consecutive reactions: 1 ) the gasification of char by $\mathrm{CO}_{2}$ and $\mathrm{O}_{2}$ for production of $\mathrm{CO}$, and, 2) the removal of surface oxygen complexes, including those formed after adsorption of NO, by gaseous CO, for the regeneration of reactive sites, i.e., $\mathrm{C}(\mathrm{O})+\mathrm{CO}_{(\mathrm{g})} \leftrightarrow \mathrm{CO}_{2}+\mathrm{C}_{\mathrm{f}}$. The observed high $\mathrm{CO}$ productions and $\mathrm{CO}$ scavenging surface oxides, $\mathrm{C}(\mathrm{O})$, in reburning are consistent with the published work on char gasification. The role of CO in scavenging surface oxides have been discussed by Reif (1952), Blackwood and Ingeme (1960), Laurendeau (1978), Levy et al. (1981), Chan et al. (1983), De Soete (1990), Calo and Hall (1991), Chen et al. (1993), and Molina et al. (2000).

\section{Design of Mixed Fuels for Effective Reburning}

The mechanistic discoveries discussed in the last section suggested a new route for effective reduction of NO in reburning. This is accomplished by using a mixed fuel containing the following two functions:

- $\quad$ a gaseous hydrocarbon component that produces free radicals in the reburning flame for effective reduction of NO, and,

- a catalyst for effective conversion of $\mathrm{HCN}$ to $\mathrm{NH}_{3}$.

Fly ashes have been considered industrial wastes that have little commercial value. Therefore, our focus of the second component has been placed on the ashes produced from 
utilities and other power plants; the cost of such an approach involves transportation expenses only. Moreover, carbon in the ashes is likely to enhance the NO conversion.

We have demonstrated that over $90 \%$ of NO from the primary flame can be reduced at a stoichiometric ratio (SR) 0.9 at $1100^{\circ} \mathrm{C}$ by methane reburning (Burch et al., 1991). Moreover, the NO reduction efficiency is higher at higher temperatures implying the same NO reduction efficiency may be achievable with less reburning fuel at normal flame temperatures, $1100^{\circ} \mathrm{C}$ to $1700^{\circ} \mathrm{C}$. They also demonstrated that the additional NO reduction due to higher temperature is accompanied with higher HCN production; thus catalytic HCN conversion in reburning stage is desirable.

Based on the HCN reduction efficiency reported by Chen and Tang (2001), 130 tonnes of lignite fly ash is needed everyday for a 172MWe bituminous-fired power plant. Lignite productions in the US, however, are limited to the Northern Great Plains (North and South Dakota and Montana), and Southern US (Texas, Louisiana, and Mississippi). Although it is not a major cost factor, transporting lignite ash from the lignite-fired power plants to the utilities and industries in eastern states still consists a cost concern.

Ashes derived from sub-bituminous coals have also been considered candidates as the secondary component. It is known that sub-bituminous coals often possess properties closer to lignite than bituminous coals. Although the contents of catalytic components in sub-bituminous coals are lower than those in lignite, we study the catalytic activities of the products of sub-bituminous coals in this project to explore their applicability in reburning so that technology can be geographically available to a larger number of power plants in the US, see Figure 2.

Another widely available resource, Material X, has been studied to increase the 
applicability and effectiveness of mixed fuel reburn. The discussion on the advantages of Material $\mathrm{X}$ as a reburn fuel is found in Appendix 1 of the second part of this report. The properties and handling of Material X, and results from and economic analysis for mixed fuels involving Material X in the subsequent discussions are also included as appendices in the second part of this report, which will be released after a provisional patent is secured.

\section{Objective and Scope}

The objective of this program is to experimentally verify the concept discussed above. A wide spectrum of mixed fuel has been selected and tested in a simulated reburning apparatus. Moreover, industrial collaborations have been vigorously sought in the US and China to bring this concept to a technological fast track. 


\section{EXECUTIVE SUMMARY}

Pilot and full-scale demonstration research in the last three decades have suggested that reburning possesses a $60 \%$ NO reduction floor. Although $90 \%$ of NO can be effectively reduced in the reburning zone by natural gas, nitrogen-containing reaction products from this second stage of the process are likely the precursors of the NO production in the burnout zone, which ultimately contribute to the observed $60 \%$ NO reduction floor. During natural gas reburning, hydrocarbon free radicals, including $\mathrm{C}$, $\mathrm{CH} \cdot$ and $\mathrm{CH}_{2}$, chemically reduce NO to $\mathrm{HCN}$, a major reaction products in reburning zone. A significant portion of HCN oxidizes to NO in the burnout zone that limits the overall NO reduction efficiency. During coal reburning, a significant portion of the char nitrogen oxidizes to form NO in the burnout zone. To break these reduction barriers, advanced reburning must involve means for simultaneously minimizing $\mathrm{NO}$, and its reaction intermediates, i.e., HCN and char.

Recent studies of heterogeneous reburning, i.e., reburning involving a coal-derived char (Chen and Ma, 1996; Chen and Tang, 2001), have revealed its variables, kinetics and mechanisms. Young chars derived from low rank coals, lignite and sub-bituminous coal, contain catalysts that effectively reduce not only NO, but also HCN. Gaseous CO, a rich product of incomplete combustion in a reburning stage, effectively scavenges surface oxides and regenerate the carbon active sites on the char surface. The mechanistic information renders it possible to design a highly efficient reburning fuel.

Mixed fuels containing these multiple functions have been designed and tested in a simulated, bench-scale reburning apparatus at $1100^{\circ} \mathrm{C}$ with a $0.2 \mathrm{~s}$ residence time. Reburning experiments were carried out in a ceramic flow reactor with a simulated flue gas consisting of $16.8 \% \mathrm{CO}_{2}, 1.95 \% \mathrm{O}_{2}$, and $0.1 \% \mathrm{NO}$ in a helium base. These concentrations of $\mathrm{CO}_{2}, \mathrm{O}_{2}$, and $\mathrm{NO}$ were chosen to be consistent with those of a coal primary flame operated at a stoichiometric ratio of 1.1. Methane is usually used as one of the components for its capability of converting $\mathrm{NO}$ to $\mathrm{HCN}$ and for the speedy production of $\mathrm{CO}$ for scavenging surface oxides, if char is present in the system. A second component is chosen mainly for the effective reduction of $\mathrm{HCN}$; they include lignite ashes, ashes of sub-bituminous coals, ashes from utility boilers, ashes from Bunsen burners, and a certain Material X.

In general, HCN reduction always increases with higher amount of these secondary fuels. Ashes of sub-bituminous coals are much less reactive than those of lignite. Ashes collected from utilities are less effective than those from laboratory by a Bunsen burner, probably due to the differences in their temperature history and level of sintering. Ash collected from a bag-house seems to be more effective in HCN reduction than ashes from electrostatic precipitators; moreover, the ash from a bag-house is capable of reducing another reaction intermediate, $\mathrm{NH}_{3}$. Remarkably high efficiencies of $\mathrm{NO}$ and $\mathrm{HCN}$ reductions have been observed. For instance, when methane and ashes from lignite-fired power plants are used, about $90 \%$ of NO is converted to species other than NO and HCN.

To render the mixed fuel concept accessible to the power plants away from the lignite resources, the potential of using other widely available materials was tested. The complete Executive Summary that briefs on results from using these materials is in the second part of this report, which will be released once the provisional patent is secured.

In conclusion, our quantifications of total fixed nitrogen ( $\mathrm{NO}, \mathrm{HCN}$ and $\mathrm{NH}_{3}$ ) suggest that, by careful design of a mixed fuel, reburning technology is likely to meet the 
US Environmental Protection Agency's regulation of removing $85 \%$, or $0.15 \mathrm{lb} / \mathrm{million}$ $\mathrm{Btu}$, of $\mathrm{NO}_{\mathrm{x}}$ in a three-stage reburning process. Efforts have been made in this project to demonstrate these discoveries in pilot- and full-scale boilers in the near future. 


\section{EXPERIMENTAL}

\section{A. Apparatus for Simulated Reburning}

Reburning experiments were carried out in a ceramic flow reactor (Burch et al., 1991; Burch et al., 1994; Chen and Ma, 1996) with a simulated flue gas consisting of $16.8 \% \mathrm{CO}_{2}, 1.95 \% \mathrm{O}_{2}$, and $0.1 \% \mathrm{NO}$ in a helium base. These concentrations of $\mathrm{CO}_{2}, \mathrm{O}_{2}$, and NO were chosen to be consistent with those of a coal primary flame operated at a stoichiometric ratio of 1.1. Helium, instead of nitrogen, was used as the base gas to minimize the heat-up time after the gas enters the reactor at room temperature. The flow reactor was an alumina tube (Bolt Technical Ceramics) with an inside diameter of $1.91 \mathrm{~cm}$ and an overall length of $64 \mathrm{~cm}$. The central portion of the reactor tube was enclosed in a 30-cm long, electrically heated furnace (Lindberg Model 55035), which provided tube temperatures up to $1150^{\circ} \mathrm{C}$. A particle feeder, which utilized controlled aerodynamic stripping of the powder surface by passing a carrier gas through a narrow, concentric space between a cylindrical piston and the inner wall of particle reservoir to affect the feed rate, was designed, fabricated, utilized (Burch et al., 1991) and modified (Tang and Chen, 2001) for delivering coal, char and catalyst particles at low and steady rates. For ashes with strong cohesive forces, particles tend to agglomerate and smooth feeding becomes difficult. Nevertheless, this problem can be avoided by diluting the ash samples with chromatographic silica gel particles. Silica gel particles have been experimentally demonstrated to be chemically inert to the reactions discussed herein.

Most of the experiments were conducted at $1100^{\circ} \mathrm{C}$. Ashes were usually fed at 0.01 to $0.05 \mathrm{~g} / \mathrm{min}$; the former corresponds to the ash feeding rates when lignite is used in reburning at a stoichiometric ratio (SR2) of about 0.9. The gas residence time in 
isothermal zone is about $0.2 \mathrm{~s}$. The SR2 was selected because the NO reduction is optimal, about 90\% (Burch et al., 1991).

Fixed gas species of interest were monitored by an on-line instrument package. The analyses included $\mathrm{NO}_{\mathrm{x}}$ (Chemiluminescence based, Thermo Environmental Instruments Model 42C), $\mathrm{CO}$ and $\mathrm{CO}_{2}$ (infrared based, California Analytical Instruments Model ZRH), and $\mathrm{N}_{2} \mathrm{O}$ (infrared based, Horiba Model VIA-510). At the beginning of this project, it was observed that the $\mathrm{NO}_{\mathrm{x}}$ analyzer used in the past, a Thermo Electron Model 10A, had several problems, and Thermal Environmental Instruments had stopped manufacturing the parts. Therefore, a new $\mathrm{NO}_{\mathrm{x}}$ analyzer was purchased using University funds in June, 2003. Differences between the base gas used for the calibration gas and sample gas were found to produce significant instrument error. This is particularly true for chemiluminescent $\mathrm{NO}_{\mathrm{x}}$ measurement, which relies on a constant gas flow through capillary tubes. Thus each of these instruments was calibrated with a gas mixture representative of the feed gas composition.

Diverting the reactor effluent through a straight tube impinger filled with $0.5 \mathrm{~L}$ of $0.1 \mathrm{~N} \mathrm{HNO}_{3}$ aqueous solution for a specified time interval collected the reaction intermediates, $\mathrm{HCN}$ and $\mathrm{NH}_{3}$. The captured solutions were $\mathrm{pH}$ adjusted with $\mathrm{NaOH}$ and analyzed for $\mathrm{CN}^{-}$and dissolved ammonia with specific ion electrodes (Thermo Orion). Poisoning of the cyanide electrode by sulfur ions was prevented by adding an aqueous solution of $\mathrm{Pb}\left(\mathrm{NO}_{3}\right)_{2}$ prior to adding the $\mathrm{NaOH}$. Sulfide ions were precipitated as $\mathrm{PbS}$. Due to the acidic nature of the impinger solution, recovery of $\mathrm{HCN}$ and $\mathrm{NH}_{3}$ by this method was tested using known standards and found to be near quantitative for $\mathrm{NH}_{3}$ but only $70 \%$ for $\mathrm{HCN}$ in the range of 100 to $700 \mathrm{ppm}$ of $\mathrm{HCN}$. Thus, $\mathrm{NH}_{3}$ values have been 
presented as measured while HCN values reported have been corrected for collection efficiency.

Most of the experiments were carried out twice to ensure data integrity. The conclusions drawn in this report are based on data from multiple runs well below $10 \%$ of errors.

BET surface area analysis of the samples used was done by a Quantachrome Corporation, NOVA 2200 Multi-Station High Speed Gas Sorption Analyzer Version 7.11. The surface areas of selected ashes were analyzed by BET method with nitrogen at 77.4 Kelvin.

\section{B. Samples}

Reburning was conducted with a mixture of methane and selected ashes. A suite of ash samples were either produced in our laboratory by a Bunsen burner or collected from power plants in the United States. Samples of Material X are described in Appendix 2 of the second part of this report.

They include the following:

1. North Dakota lignite lab-produced ash - the raw lignite was collected at the Beulah mine, and a Bunsen burner produced its ash in a ceramic crucible at about $650^{\circ} \mathrm{C}$.

2. Stanton Station Unit \#1 - this fly ash was collected from an electrostatic precipitator of a lignite-fired boiler.

3. Stanton Station Baghouse - this fly ash sample was collected from a dust bag of a lignite-fired boiler.

4. Coal Creek Station - this fly ash was collected from a lignite-fired boiler; the means 
of collection was not specified.

5. Columbig U\#2 - this fly ash was collected from a sub-bituminous coal-fired boiler; the means of collection was not specified.

6. Chinese subbituminous lab produced ash - this is a mixture of a high-rank coal from Zhunger, China, and a low-rank coal from Shenhua, China. It is blended to increase the overall fusion point and avoid slagging by a power plant in China. Its ash was produced in a ceramic crucible by a Bunsen burner at about $650^{\circ} \mathrm{C}$. 


\section{RESULTS AND DISCUSSION}

\section{A. Reconstruction of the Apparatus and Development of New Procedure}

The simulated reburning system in our laboratory was originally fabricated in 1987 , and it required a major overhaul at the outset of this award. Essentially all rotameters, tubing and fittings, pressure gauges, regulator for the gas cylinders have been replaced. The flow manifolds between the reactor and the sampling train was redesigned and fabricated for efficient handling. Parts of the furnace were replaced for more accurate temperature control and reading. The $\mathrm{CN}^{-}$and $\mathrm{NH}_{4}{ }^{+}$specific ion detectors were also replaced for accurate measurements of $\mathrm{HCN}$ and $\mathrm{NH}_{3}$, respectively. The $\mathrm{CO}_{2} / \mathrm{CO}$ analyzer was sent back to the manufacturer and serviced; parts were replaced.

With the financial support of the University, a new NO analyzer (Thermo Environmental Instruments Model 42C, and a new furnace for char preparation (Blue M HTF55342C and its controller Blue M CC58114C) were purchased and installed.

Lignite ashes form snowflake-like deposits on the inner surface in the downstream section (where the gas temperature starts to drop) of the reactor wall. These deposits can usually be brushed off with acetone. This procedure regenerates the tube's normal (inert) activity, which was confirmed by reburning with methane. The discussion on the procedure to handle Material X is found in Appendix 3 of the second part of this report.

\section{B. Effects of Coal-Derived Fly Ashes}

Figure 3 illustrates the effects of coal-derived ashes during reburning with methane at stoichiometric ratio (SR2) 0.9. This SR2 is selected because maximum NO reduction was observed at SR2 = 0.9 in our earlier study (Burch et al., 1991). In most cases, addition 
of an ash at $0.01 \mathrm{~g} / \mathrm{min}$ feeding rate enhances the reduction of HCN, signifying its likely effect on the final yield of NO from a burnout stage. This ash feeding rate corresponds to ash loading found in lignite reburning at SR2 $=0.9$. Among these ashes, the ash derived from North Dakota's lignite and prepared in our laboratory in a Bunsen burner has the highest catalytic reactivity. Lignite ashes from utility boilers show lower reactivity probably due to ash sintering at high temperatures in utility boilers. The laboratory ash is typically prepared at $650^{\circ} \mathrm{C}$, while the utility ash has usually experienced a much higher temperature history, 1100 to $1700^{\circ} \mathrm{C}$. Results in Figure 3 also suggest that ash derived from a sub-bituminous coal has a lower catalytic activity than those of lignite. In fact, at this particular ash feed rates, the effects of ash from the sub-bituminous coal are within the statistical errors of the experimental data from methane reburning.

Increasing the ash loading always enhances the HCN conversion, as illustrated in Figure 4. Remarkably high HCN reductions are achieved when the feeding rate is increased to $0.05 \mathrm{~g} / \mathrm{min}$. For instance, about $90 \%$ of $\mathrm{NO}$ is converted to species other than NO and HCN when methane and lignite ashes from lignite-fired power plants are used. The bag-house ash seems to be particularly effective; it catalytically reduces both HCN and $\mathrm{NH}_{3}$. This bag-house ash has high content of sodium, magnesium, and iron, (Table 1) and a higher surface area than the other power plant ashes (Table 2). Nevertheless, further investigations will be needed to elucidate the exact chemistry.

The discussion on the effects and the economic advantages of Material $\mathrm{X}$ is found in Appendices 4 and 5 of the second part of this report. 


\section{Technology Transfer}

Wei-Yin Chen and Hamid Sarv of the Babcock and Wilcox (B\&W) Company developed an invention entitled In-Furnace Reduction of Nitrogen Oxide by Mixed Fuels Involving a Material $X$ during the course of this study. An invention disclosure has been documented. The invention was built upon the chemical reaction mechanisms and experimental verifications of the concept discussed in the second part of this report as Appendices.

Active collaborations have been sought to bring our discoveries to the technological fast track. During the program period, we have discussed the concept of using mixed fuel for reburning with a large group of organizations in the US and abroad:

- Babcock and Wilcox

- University of North Dakota’s Energy and Environmental Research Center $($ EERC)

- Lignite Energy Council

- GE Energy

- Red Hills Power Station

- Xian Jiaotong University, Xian China

- Zhejiang University, Hangzhou, China

- Donghua University, Shanghai, China

- Thermal Power Research Institute, Xian, China

- Dongfang Boiler Works, Zigong, China

- Wuhan Boiler Works, Wuhan, China

Wei-Yin Chen visited EERC to promote the reburning technology and the lignite 
resources of North Dakota and Mississippi. Representatives from the Lignite Energy Council and a lignite-fired power plant were also present during the meeting. A seminar on our accomplishments was delivered during his visit. EERC was invited to demonstrate our concept on their larger scale unit in Phase II of our DOE project. After positive results are successfully demonstrated on the EERC's furnace, the University of Mississippi and EERC plan to submit a joint proposal to the Lignite Energy Council and the DOE to take the concept to a utility boiler.

Several configurations of firing the mixed reburning fuel with utility boilers was discussed with $\mathrm{B} \& \mathrm{~W}$ engineers. Tests with a B\&W facility will be costly and we plan to wait for proper DOE solicitations for such a demonstration. Possible research collaboration with GE Energy is on going.

China is the world's largest coal consumer. China will start charging fees for excessive NO and other pollutants emissions from coal-fired boilers on July 1, 2004. Therefore, our NO control experience is highly desirable in China. To establish collaborative projects, Wei-Yin Chen spent about one month in China to promote the mixed fuel concept. He attended the Fifth Asia-Pacific Conference on Combustion, and the Fourth International Conference on Coal Combustion; both were held in Nanjing, November 23 - 26, 2003. Subsequently, he visited the universities and utilities mentioned above. He delivered papers or lectures on reburning everywhere he went. To continue the dialogs and initiate the collaborations with these Chinese organizations, he was invited to serve as a adjunct professor of Xian Jiaotong University, a member of the international scientific committee of the Fifth International Symposium on Multiphase Flow, Heat and Mass Transfer, and Energy Conversion to be held in Xian, July 3-8, 2005, and a member of 
the international advisory committee of the Third International Conference on Combustion, Incineration / Pyrolysis, and Emission Control to be held in Hangzhou, October 21-23, 2004. A proposal has been submitted by Donghua University to the Chinese government for supporting a faculty member to work at the University of Mississippi for one year. Possibility of submitting other joint proposals has also been planned. It is expected that joint projects will be developed with some of these organizations in the next year.

\section{CONCLUSION}

Our quantifications of total fixed nitrogen $\left(\mathrm{NO}, \mathrm{HCN}\right.$ and $\left.\mathrm{NH}_{3}\right)$ in a simulated reburning apparatus suggest that, by careful design of a mixed fuel based on recently elucidated reaction mechanisms, a single reburning technology is likely to significantly break the $60 \%$ reduction floor observed in the last three decades. It is expected to meet the Environmental Protection Agency’s regulation of removing 85\%, or $0.15 \mathrm{lb} /$ million Btu, of $\mathrm{NO}_{\mathrm{x}}$ in boilers. Since the invention involves only low-cost lignite or Material $\mathrm{X}$ (see the second part of this report, which will be released once a provisional patent is secured), the technological and economical impact of this study is enormous. We strongly urge continued investigations of reburning by mixed fuels, both at bench scale and pilot scale levels.

\section{REFERENCES}

Allen, D., "The Removal of Gaseous Pollutants during Coal Combustion," Ph.D. Dissertation, University of Cambridge, Cambridge, England, 1991. 
Bonskowski, R., “U.S. Coal Reserves: 1997 Update,” Energy Information Administration, Office of Coal, Nuclear, Electric and Alternate Fuels, Office of Integrated Analysis and Forecasting, U.S. Department of Energy, p. 3 (1997).

Bueno-Lopez, A., A. Garcia-Garcia, C. Salinas-Martinez de Lecea, C. McRae, and C. E. Snape, "Low-Cost Potassium-Containing Char Briquettes for $\mathrm{NO}_{\mathrm{x}}$ Reduction," Energy \& Fuels, 16, 997-1003 (2002).

Burch, T.E., F. R. Tillman, W.Y. Chen, T.W. Lester, R.B. Conway, and A.M. Sterling, "Partitioning of Nitrogenous Species in the Fuel-Rich Stage of Reburning," Energy \& Fuels, 5, 231-237 (1991).

Blackwood, J. D., and A. J. Ingeme, “The Reaction of Carbon with Carbon Dioxide at High Pressure,” Aust. J. Chem., 13, 194-209 (1960).

Burch, T.E., W.Y. Chen, T.W. Lester, and A.M. Sterling, "Interactions of Fuel Nitrogen with Nitric Oxide during Reburning with Coal," Combustion \& Flame, 98, 391-401 (1994).

Calo, J. M., and P. J. Hall, “Applications of Energetic Distributions of Oxygen Surface Complexes to Carbon and Char Reactivity and Characterization,” in "Fundamental Issues in Control of Carbon Gasification Reactivity,” ed. J. Lahaye and P. Ehrburger, Kluwer Academic Publishers, Dordrecht, The Netherlands, pp.329-368 (1991).

Chan, L. K., A. F. Sarofim, and J.M. Beer, "Kinetics of the NO-Char Reaction at Fluidized Bed Combustor Conditions," Comb. \& Flame, 52, 37-45 (1983).

Chen, S.G., R.T. Yang, K. Kapteijn, and J.A. Moulijn, “A New Surface Oxygen Complex on Carbon: Toward a Unified Mechanism for Carbon Gasification Reactions,” Ind. 
Eng. Chem. Res., 32, 2835-2840 (1993).

Chen, W.Y., and L. Ma, "Extent of Heterogeneous Mechanisms during Reburning of Nitrogen Oxide," AIChE Journal, 42, 1968-1976 (1996).

Chen, W.Y., and L. Tang, "Variables, Kinetics and Mechanisms of Heterogeneous Reburning," AIChE Journal, 47, 2781-2797 (2001).

De Soete, G.G., "Reduction of Nitric Oxide by Solid Particles," in "Pulverized Coal Combustion: Pollutant Formation and Control, 1970-1980,” EPA-600/8-90-049, pp.8-1 to 8-59 (1990).

Garcia-Garcia, A., M.J. Illan-Gomez, A. Linares-Solano, and C. Salinas-Martinez de Lecea, "Potassium-Containing Briquetted Coal for the Reduction of NO," Fuel, 76, 499-505 (1997).

Guo, F., and W. Hecker, "Kinetics of NO Reduction by Char: Effects of Coal Rank," Twenty-Seventh Symp. (Int'l) on Combustion, The Combustion Institute, 3085-3092 (1998).

Hansen, P.F.B., K. Dam-Johansen, J.E. Johnsson, and T. Hulgaard, "Catalytic Reduction of $\mathrm{NO}$ and $\mathrm{N}_{2} \mathrm{O}$ on Limestone during Sulfur Capture under Fluidized Bed Combustion Conditions," Chem. Eng. Sci., 47, 2419-2424 (1992).

Hansen, P.F.B., and K. Dam-Johansen, "Limestone Catalyzed Reduction of $\mathrm{NO}$ and $\mathrm{N}_{2} \mathrm{O}$ under Fluidized Bed Combustion Conditions," Proceedings of the 1993 Int'l Conf. on Fluidized Bed Combustion, ASME, 2, 779-787, 1993.

Hengel, T. D., and P. L. Walker, "Catalysis of Lignite Char Gasification by Exchangeable Calcium and Magnesium," Fuel, 63, 1214-1220 (1984).

Illan-Gomez, M. J., A. Linares-Solano, L. R. Radovic, and C. Salinas-Martinez de Lecea, 
"NO Reduction by Activated Carbons. 2. Catalytic Effect of Potassium," Energy \& Fuels, 9, 97-103 (1995a).

Illan-Gomez, M. J., A. Linares-Solano, L. R. Radovic, and C. Salinas-Martinez de Lecea, "NO Reduction by Activated Carbons. 3. Influence of Catalyst Loading on the Catalytic Effect of Potassium," Energy \& Fuels, 9, 104-111 (1995b).

Illan-Gomez, M. J., A. Linares-Solano, L. R. Radovic, and C. Salinas-Martinez de Lecea, "NO Reduction by Activated Carbons. 4. Catalysis by Calcium," Energy \& Fuels, 9, 112-118 (1995c).

Illan-Gomez, M. J., A. Linares-Solano, L. R. Radovic, and C. Salinas-Martinez de Lecea, "NO Reduction by Activated Carbons. 5. Catalysis by Iron," Energy \& Fuels, 9, 540-548 (1995d).

Illan-Gomez, M. J., A. Linares-Solano, and C. Salinas-Martinez de Lecea, "NO Reduction by Activated Carbons. 6. Catalysis by Transition Metals," Energy \& Fuels, 9, 976-983 (1995e).

Illan-Gomez, M. J., A. Linares-Solano, L. R. Radovic, and C. Salinas-Martinez de Lecea, "NO Reduction by Activated Carbons. 7. Some Mechanistic Aspects of Uncatalyzed and Catalyzed Reaction," Energy \& Fuels, 10, 158-168 (1996).

Jensen, A., J. E. Johnsson, and K. Dam-Johansen, “Catalytic and Gas-Solid Reactions Involving HCN over Limestone,” AIChE Journal, 43, 3070-3084 (1997).

Kern, K. C., and G. Vaux, "Future Trends in the Natural Gas Market,” Paper presented at the 2004 Conference on Reburning for $\mathrm{NO}_{\mathrm{x}}$ Control, Morgantown, WV, May 18, 2004; http://www.netl.doe.gov/publications/proceedings/04/NOx/b8.50kern-presentatio 
n.pdf.

Laurendeau, N.M., “Heterogeneous Kinetics of Coal Char Gasification and Combustion,” Prog. Energy Combust. Sci., 4, 221-270 (1978).

Levy, J.M., L.K. Chan, A.F. Sarofim, and J.M. Beer, "NO/Char Reactions at Pulverized Coal Flame Conditions," 18th Symp. (Int'l) on Combustion, The Combustion Institute, pp.111-120 (1981).

Lin, W., J.E. Johnsson, K. Dam-Johansen, and C. M. Van den Bleek, "Interactions between $\mathrm{NO}_{\mathrm{x}}$ Emission and Desulfurization in FBC," Proceedings of the 1993 Int'l Conf. on Fluidized Bed Combustion, ASME, 2, 1093-1100, 1993.

Lizzio, A.A., H. Jiang, and L.R. Radovic, “On the Kinetics of Carbon (Char) Gasification: Reconciling Models with Experiments,” Carbon, 28, 7-19 (1990).

Miller, J.A., and C.T. Bowman, "Mechanism and Modeling of Nitrogen Chemistry in Combustion," Prog. Energy \& Combustion Sci., 15, 287-337 (1989).

Mims, C.A., “Catalytic Gasification of Carbon: Fundamentals and Mechanism,” in “Fundamental Issues in Control of Carbon Gasification Reactivity,” ed. J. Lahaye and P. Ehrburger, Kluwer Academic Publishers, Dordrecht, The Netherlands, pp.383-407 (1991).

Molina, A., E. G. Eddings, D. W. Pershing, and A. F. Sarofim, “Char Nitrogen Conversion: Implications to Emissions from Coal-Fired Utility Boilers,” Progress in Energy and Combust. Science, 26, 507-531 (2000).

Payne, R., D.K. Moyeda, P. Maly, T. Glavicic, and B. Weber, "The Use of Pulverized Coal and Coal-Water-Slurry in Reburning $\mathrm{NO}_{\mathrm{x}}$ Control," Proceedings of the EPRI/EPA 1995 Joint Symposium on Stationary Combustion $\mathrm{NO}_{\mathrm{x}}$ Control, Book 4, Kansas 
City, Missouri, May 16-19, 1995.

Pershing, D.W., personal communication with W.Y. Chen (1995).

Radovic, L. R., P. L. Walker, Jr., and R. G. Jenkins, "Importance of Catalyst Dispersion in the Gasification of Lignite Chars," J. of Catalysis, 82, 382-394 (1983).

Reif, A.E., “The Mechanism of the Carbon Dioxide - Carbon Reaction,” J. Phys. Chem., 56, $785-788$ (1952).

Shimizu, T., D. Fujita, K. Ishizu, S. Kobayashi, and M. Inagaki, "Effects of Limestone Feed on Emissions of $\mathrm{NO}_{\mathrm{x}}$ and $\mathrm{N}_{2} \mathrm{O}$ from a Circulating Fluidized Bed Combustor," Proceedings of the 1993 Int'l Conf. on Fluidized Bed Combustion, Vol. 1, ASME, pp.611-617, 1993.

Takahashi, Y., M. Sakai, T. Kunimoto, S. Ohme, H. Haneda, T. Kawamura, and S. Kaneko, "Development of MACT In-Furnace $\mathrm{NO}_{\mathrm{x}}$ Removal Process for Steam Generators," Proc. 1982 Joint Symp. Stationary Combustion $\mathrm{NO}_{\mathrm{x}}$ Control, Vol. 1," EPRI Report No. CS-3182, July, 1983.

Wendt, J.O.L., C.V. Sternling, and M.A. Matovich, "Reduction of Sulfur Trioxide and Nitrogen Oxides by Secondary Fuel Injection," 14-th Symp. (Int'l) Combustion, The Combustion Inst., Pittsburgh, PA, p.897 (1973) 
Table 1: Analysis of the Samples (Weight \%, Dry Basis)

\begin{tabular}{|c|c|c|c|c|c|c|c|c|c|c|c|c|}
\hline $\begin{array}{c}\text { Sample } \\
\end{array}$ & $\mathrm{Na}_{2} \mathrm{O}$ & MgO & $\mathrm{Al}_{2} \mathrm{O} 3$ & $\mathrm{SiO}_{2}$ & $\mathrm{P}_{2} \mathrm{O}_{5}$ & $\mathrm{SO}_{3}$ & $\mathrm{~K}_{2} \mathrm{O}$ & $\mathrm{CaO}$ & TiO & $\mathrm{MnO}_{2}$ & $\mathrm{Fe}_{2} \mathrm{O}_{3}$ & LOI \\
\hline Coal Creek Station Lignite Fly Ash & 3.07 & 4.17 & 17.04 & 50.1 & 0.23 & 1.43 & 2.32 & 16.72 & 0.86 & 0.05 & 7.26 & 0.08 \\
\hline Stanton Station Baghouse Lignite Fly Ash & 3.2 & 5.83 & 16.43 & 35.51 & 0.18 & 5.99 & 1.25 & 21.17 & 0.86 & 0.07 & 9.53 & 2.28 \\
\hline Stanton Station Unit\#1 Lignite Fly Ash & 1.73 & 3.54 & 14.21 & 22.46 & $<0.02$ & 20.64 & 0.95 & 31.69 & 0.83 & 0.05 & 4.66 & 0.46 \\
\hline North Dakota Lignite Coal & 4.6 & 7.03 & 9.87 & 20.3 & 0.44 & 21.08 & 0.39 & 22.46 & - & $\begin{array}{c}0.12 \\
\left(\mathrm{Mn}_{3} \mathrm{O}_{4}\right)\end{array}$ & 9.09 & - \\
\hline
\end{tabular}

\begin{tabular}{|c|c|c|c|c|c|c|c|c|}
\hline & $\mathrm{Na}_{2} \mathrm{O}$ & MgO & $\mathrm{Al}_{2} \mathrm{O}_{3}$ & $\mathrm{SiO}_{2}$ & $\mathrm{~K}_{2} \mathrm{O}$ & $\mathrm{CaO}$ & $\mathrm{Fe}_{2} \mathrm{O}_{3}$ & $\mathrm{TiO}_{2}$ \\
\hline Chinese Blended Coal - Ash Analysis & 0.68 & 1.47 & 36.14 & 35.65 & 0.43 & 10.16 & 10.75 & 1.90 \\
\hline
\end{tabular}

\begin{tabular}{|c|c|c|c|c|c|c|}
\hline Chinese Blended Coal - Proximate Analysis & & Fixed Carbon & \multicolumn{2}{|c|}{ Volatile Matter } & Ash & Moisture \\
\hline Chinese Blended Coal - Elemental Analysis & 54.87 & 3.43 & 9.62 & 0.8 & 0.36 & 20993 \\
\hline
\end{tabular}


Table 2: BET Surface Areas of the Samples

\begin{tabular}{|l|c|}
\hline \multicolumn{1}{|c|}{ Sample } & BET Surface Area $\left(\mathbf{m}^{2} / \mathbf{g m}\right)$ \\
\hline Stanton Station Unit 1 Lignite Fly Ash & 0.8038 \\
\hline Stanton Station Baghouse Lignite Fly Ash & 4.776 \\
\hline & 1.201 \\
\hline Columbig U\#2 Sub-bituminous Fly Ash & \\
\hline & 3.36 \\
\hline North Dakota Lignite Bunsen Burner Ash & \\
\hline & \\
\hline
\end{tabular}




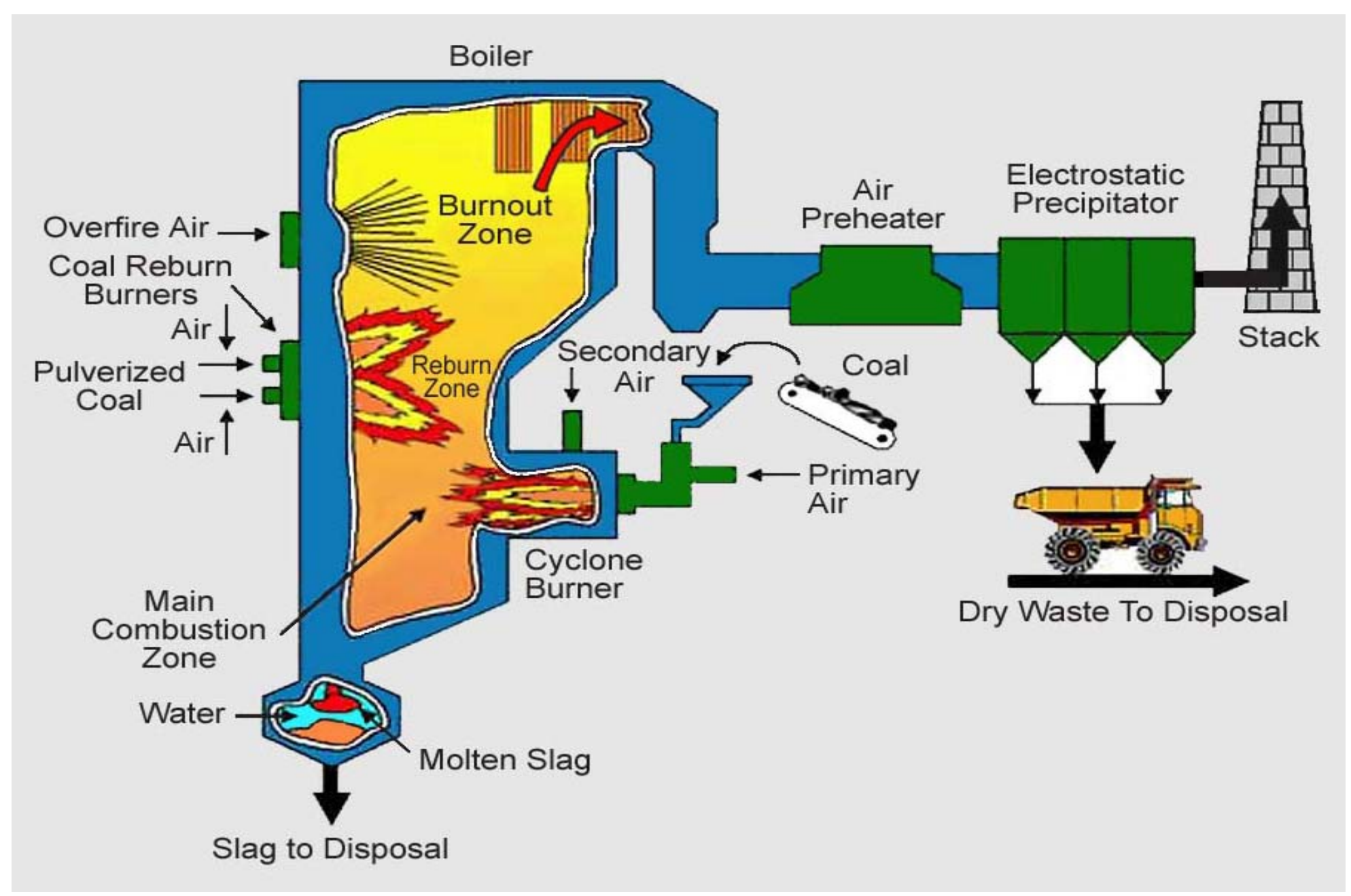

Figure 1. A Representative Reburning Process. 


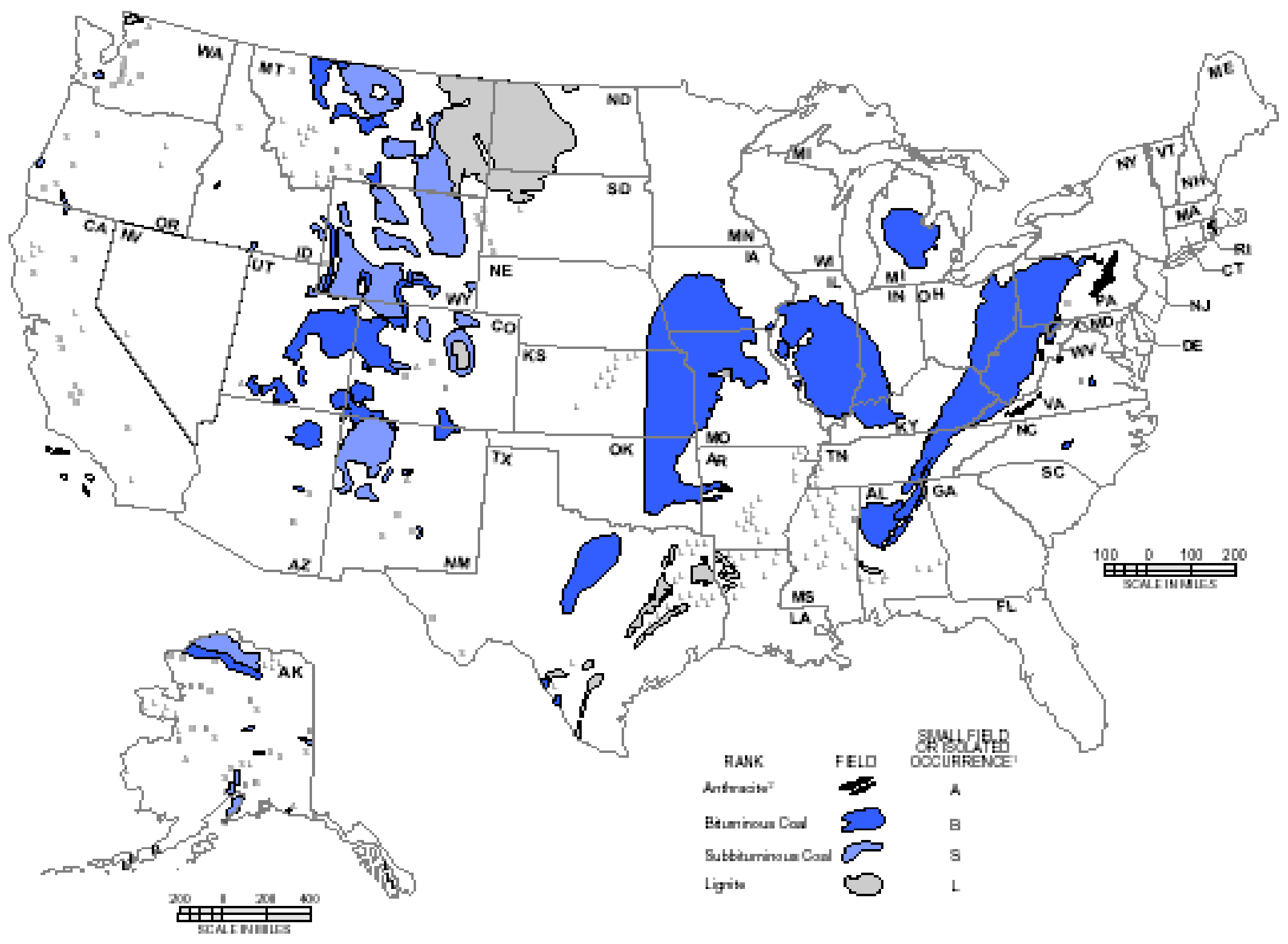

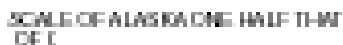

Figure 2. Distribution of Lignite and Coals in the United States (Bonskowski, 1999). 


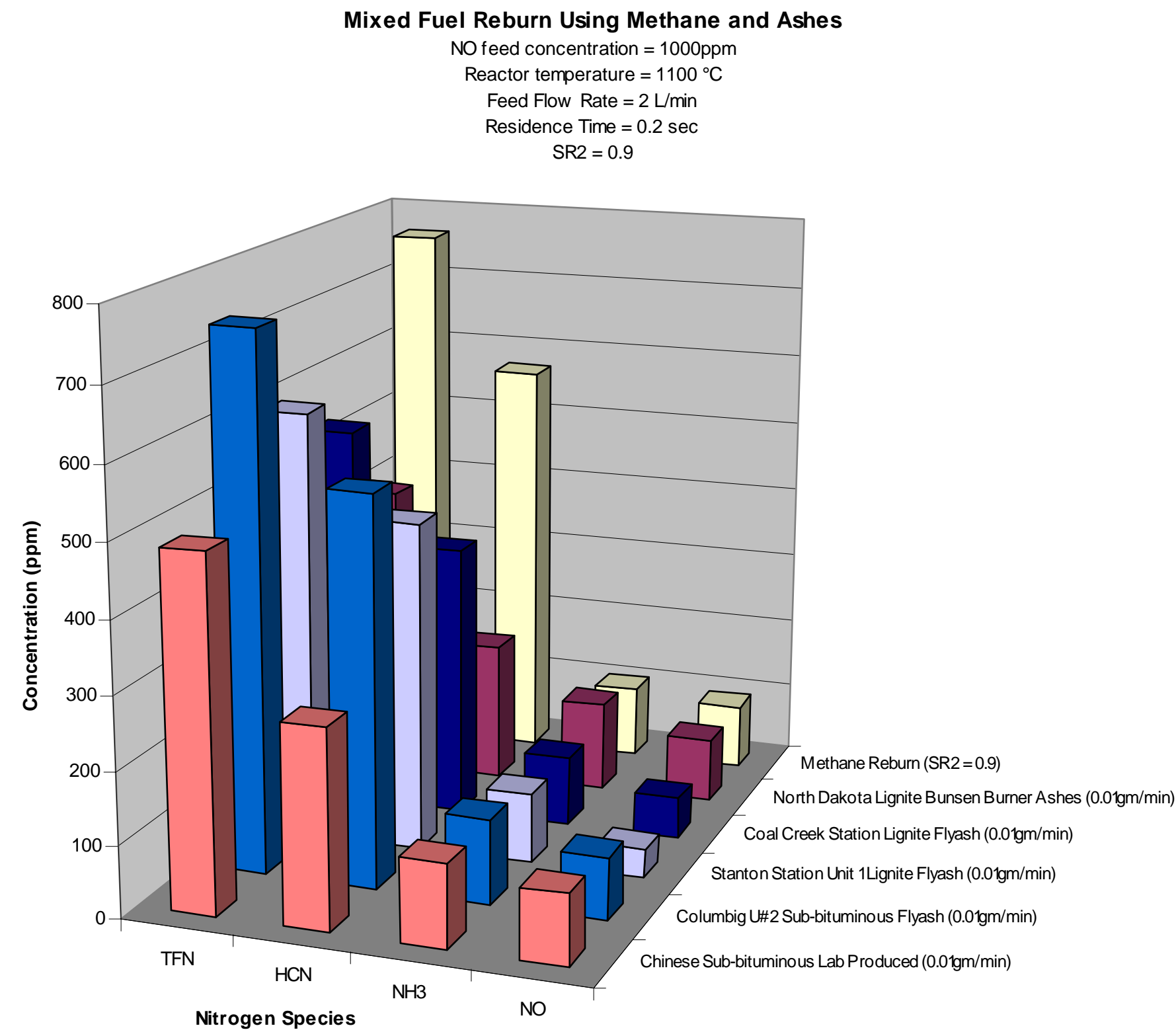

Figure 3. Effects of Lignite and Sub-bituminous Coal Ashes on Total Fixed Nitrogen Species at SR2 = 0.9 and at Ash Feed Rate of 0.01 gm/min. 
Mixed Fuel Reburn Using Methane and Ashes

NO feed concentration $=1000 \mathrm{ppm}$

Reactor temperature $=1100^{\circ} \mathrm{C}$

Feed Flow Rate $=2 \mathrm{~L} / \mathrm{min}$

Residence Time $=0.2 \mathrm{sec}$

$\mathrm{SR} 2=0.9$

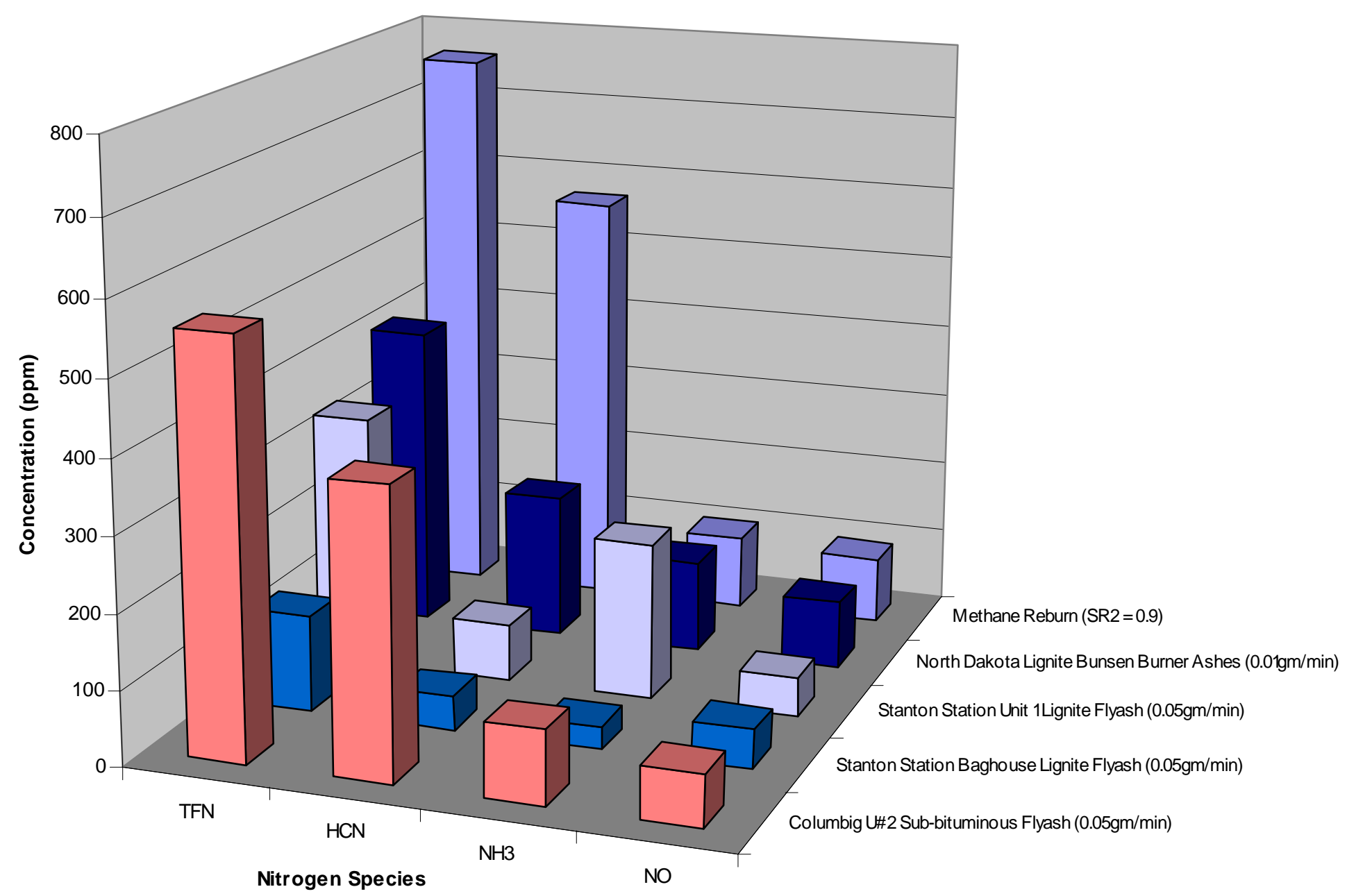

Figure 4. Effects of Lignite and Sub-bituminous Coal Ashes on Total Fixed Nitrogen Species at SR2 $=0.9$ and at Ash Feed Rate of 0.05gm/min. 